\title{
Grad Vratar (Sutiska) na putu Via Drine
}

Nina ČULJak

Filozofski fakultet

Matice hrvatske b.b.

BiH - 88000 Mostar

E-pošta: nina.culjak@ff.sum.ba
UDK: 902.2(497.6 Hercegovina)"13/17"

Izvorni znanstveni rad

Primljeno: 20. ožujka 2018.

Prihvaćeno: 30. svibnja 2018.

\section{Sažetak}

Rad donosi rezultate naših arheološko-topografskih istraživanja lokaliteta Vratar (Sutiska). Pregledom lokaliteta evidentirali smo arhitektonske ostatke Vratara te došli do zaključka da je njegov "razvoj" ka gradskom naselju u kasnom srednjem vijeku izravno uvjetovan smještajem na važnom srednjovjekovnom putu Via Drine, i to na strateški pomno izabranoj lokaciji. U radu se donose i informacije iz starih putopisa koji su opisivali put Via Drine, kao i ostatke samoga Vratara. U rad smo uključili i objavljene (nama dostupne) povijesne izvore u kojima se spominje ovaj srednjovjekovni grad. Također, utvrdili smo da je riječ o lokalitetu ograničenoga trajanja (upravo u kasnom srednjem vijeku doživljava i uspon i pad) te kao takav bi mogao poslužiti za daljnja istraživanja opusa gradnje toga vremena. U radu se također skreće pažnja na ovaj, ali i na neke druge gradove s prostora današnje Hercegovine, koji su većinom neistraženi, često neoznačeni i u fazi urušavanja.

Ključne riječi: Hercegovina; srednjovjekovni gradovi; Via Drine; gradovi hercega Stjepana Kosače; utvrda Vratar (Sutjeska/Sutiska). 


\section{Povijesni izvori i istraživanja}

Vratar je u kasnom srednjem vijeku bio u posjedu oblasnoga gospodara Stjepana Vukčića Kosače, a grad je smješten u najužem klancu rijeke Sutjeske - Prosječnici. O utvrdi $\operatorname{Vratar}^{1}$ nalazimo prve upise kod sljedećih autora: K. Jiriček, ${ }^{2}$ P. Matković, ${ }^{3}$ N. Jorga ${ }^{4}{ }^{4}$. Thallóczy, ${ }^{5}$ M. Dinić, ${ }^{6}$ H. Kreševljaković - H. Kapidžić, ${ }^{7}$ M. Vego, ${ }^{8}$ S. Ćirković, ${ }^{9}$ D. Kovačević-Kojićc ${ }^{10}$ i dr. Rezultati ovih autora navo-

1 Ovaj rad donosi rezultate istraživanja provedenih za potrebe izrade disertacije. Budući da smo kasnije došli do novih spoznaja, odlučili smo ispraviti određene pogrješke kao i nedorečenosti koje smo napravili u prethodnoj interpretaciji ovoga lokaliteta, te ih zajedno predstaviti u ovome radu.

2 Constantin Jirečen, Die Handelsstrassen und Bergwerke von Serbien und Bosnien während des Mittelalters: historisch-geographische Studien, Prag, 1879., str. 75-76.

3 Petar Matković, "Putovanje po balkanskom poluotoku XVI vieka. Putovanje B. Kuripešića, L. Nogarola i B. Ramberta", u: Rad Jugoslavenske akademije znanosti i umjetnosti, knj. LVI., Zagreb, 1881., str. 210-212.

4 Nicolae Jorga, Notes et extraits pour servir à l'histoire des croisades au XVe siècle (second série), Paris, 1899., str. 338, 408. Ovdje se navodi izvorni dokument iz 1436. god., u kojem se spominje nova carina in Sutischa), te podatak iz dubrovačkoga pisma Stjepanu Vukčiću iz 1445. godine u kojemu se Dubrovčani žale na pljačku trgovaca sotto Sutischa (pod Sutjeskom).

5 Ludwig von Thallóczy, Studien zur Geschichte Bosniens und Serbiens im Mittelalter, München - Leipzig, 1914., str. 361, 379, 398. U ovome djelu Vratar se spominje kao Vatrato, Sucisti castello con lo contato, i to u povelji Alfonsa Aragonskoga iz 1444. godine. U povelji Fridriha III. iz 1448. godine spominje se kao castrum (castrum Bratal cum omnibus pertinentiis suis), a u povelji Alfonsa Aragonskoga iz 1454. godine spominje se kao civitas (civitate Vratar cum castris et pertinentiis suis). Na ove objavljene povelje prvi je u pravom smislu skrenuo pažnju M. Dinić. Usp. Minajlo Dinić, "Zemlje hercega Svetog Save", u: Glas, CLXXXII., Beograd, 1940., str. 151-257.

6 Minajlo Dinić, "Dubrovačka srednjevekovna karavanska trgovina", u: Jugoslavenski istorijski časopis, III., Beograd, 1937., str. 24.

7 Hamdija Kreševljaković - Hamdija Kapidžić, "Stari hercegovački gradovi", u: Naše starine, II., Zavod za zaštitu spomenika kulture R BiH, Sarajevo, 1954., str. 21.

8 Marko Vego, Naselja bosanske srednjovjekovne države, Svjetlost, Sarajevo, 1957., str. 112.

9 Sima Ćir ković, Herceg Stefan Vukčić - Kosača i njegovo doba, Beograd, 1964.

10 Desanka Kojić Kovačević - Vlajko Palavestra - Zdravko Kajmaković, "Drina u doba Kosača", u: Naše starine, XIV.-XV., Sarajevo, 1981., str. 118. 
de se i u radovima novijega datuma. ${ }^{11}$ Pri tome je važno naglasiti da nigdje u objavljenoj literaturi ne postoji recentan opis građevinskih ostataka same utvrde, a također ni fotografija postojećega stanja očuvanosti. Spomen Sutjeske u izvorima iz 1430. godine veže se uz Čemerno. ${ }^{12}$ Spomen in Sutischa datira iz iste godine. ${ }^{13}$ Podatci koje između ostalih prenose S. Ćirković i D. Kovačević-Kojić, tiču se otuđenja vrijedne robe (vjerojatno srebra) Nikoli S. Gučetiću, koje je "u mjestu Sutjesci, u kastrumu zvanom Vratar"14 oduzeo sam kaštelan utvrde Vladislav Mrđenović. Ovdje nalazimo značajnim spomenuti i činjenicu da je utvrda imala svoga (očito stalnoga) kaštelana, što ne samo da ukazuje na njezinu važnost, nego i na određene uvjete koje je morala zadovoljavati da bi bila ne samo povremeno korištena stražara, nego i mjesto na kojemu se stanovalo. Također, činjenica da je kaštelan utvrde spomenut kao onaj koji je otuđio srebro trgovcima neke karavane i nije neobična, jer se u izvorima $\mathrm{u}$ istoj ulozi spominje i sam vojvoda Stjepan (npr. 1444. godine). ${ }^{15}$ To je po svoj prilici vezano uz uvođenje carine na tom mjestu koje je bilo u posjedima oblasnoga gospodara Stjepana Vukčića Kosače, dok se za konkretan slučaj s Mrđenovićem zna da se dogodio u trenutku opće pomutnje, ${ }^{16}$ nekoliko dana nakon smrti Sandalja Hranića. Zanimljivo je pitanje što se podrazumijeva pod spomenom in Sutischa. Naime, poznato

11 Primjerice u Arheološkom leksikonu BiH lokalitet je spomenut pozivanjem na navedeni rad H. Kapidžić - H. Kreševljaković iz 1954., dok je u novijim studijama o bh. srednjovjekovnim gradovima, poput ICOMOS-ove monografije Stari gradovi Bosne i Hercegovine, lokalitet opisan pretiskom navedenog upisa iz Leksikona iz 1988. god. Usp. Arheološki leksikon Bosne i Hercegovine, sv. III., Zemaljski muzej Bosne i Hercegovine, Sarajevo, 1988., str. 131; SkUPINA AUTORA, Stari gradovi Bosne i Hercegovine, Nacionalni komitet ICOMOS u Bosni i Hercegovini, Sarajevo, 2012., str. 207.

12 C. JiRečEk, Die Handelsstrassen und Bergwerke..., str. 40, bilj. 122.

13 N. JorgA, Notes et extraits..., str. 267. Vego je izgleda previdio ovaj navod kod Jorge, umjesto kojega navodi Ludw IG von THALLóczy, Studien zur Geschichte Bosniens und Serbiens im Mittelalter, München - Leipzig, 1914., i to 361. stranicu, na kojoj se spominje izvor iz 1444. god., a ne 1430., kako je navedeno. Usp. M. Vego, Naselja bosanske srednjovjekovne države, str. 112.

14 Riječ je o karavani koja je dolazila iz Srebrenice (23. svibnja 1435.). O tome: D. Kojić Kovačević - V. Palavestra - Z. Kajmaković, "Drina u doba Kosača", str. 118; S. Ćir Ković, Herceg Stefan Vukčić - Kosača i njegovo doba, str. 16-17.

15 D. Kojić Kovačević - V. Palavestra - Z. Kajmaković, "Drina u doba Kosača", str. 121.

16 S. Ćirković, Herceg Stefan Vukčić - Kosača i njegovo doba, str. 16. 
je da je Sutjeska bila srednjovjekovna župa koje se prostirala negdje od Prosječnice do iznad Tjentišta. Zna se i da je nešto sjeverniji grad Tođevac već pripadao župi Drinaljevo. ${ }^{17}$ No, pregledom objavljenih podataka iz izvora, kao i onih od kasnijih putopisaca, stječe se dojam da se već veoma rano najuži dio kanjona (oko Prosječnice) počeo nazivati imenom župe, kao centar, koji je bio branjen utvrdom iznad, a koja se također negdje naziva imenom župe. Dakle, Sutjeska/Sutiska kao župa, kao središte župe (utvrda Vratar) i kao područje najužega prolaza kroz kanjon. Tomu u prilog govori i podatak iz 1435. godine, a koji se tiče pljačke karavana (iz Srebrenice) in loco vocato Sothescha in castro vocato Vratar. ${ }^{18}$ Riječ je o prvom (do sada poznatom) spomenu Vratara u Sutjesci, u kojem se Sutjeska označava kao mjesto (iako postoje dvojbe o tumačenju značenja pojma locus u ovom kontekstu). Budući da se u nedalekom Tjentištu razvila karavanska stanica, te se mjesto općenito razvijalo prema nekom vidu trga, a bilo je otvorenoga tipa, bez svoje utvrde koja bi ga štitila, vjerojatno je Vratar u nekom smislu preuzeo tu ulogu. Već iduće 1436. godine, u izvorima su zabilježeni prigovori na novu carinu in Sutischa. ${ }^{19}$ Godine 1444. Vratar se spominje kao castello sa svojim upravnim kotarom. Ovo svakako ukazuje na brzi privredni rast mjesta. Iduće godine spominju se prigovori koji će se iznijeti zbog srebra otetoga trgovcima iz Srebrenice sotto Sutischa. ${ }^{20}$ Prvotno smo mislili da se ovdje (sotto Sutischa) ne radi o pravom podgrađu, nego baš o prostornom orijentiru, budući da se iz naše arheološko-topografske analize vidi da ovdje nije bio moguć razvoj neposrednoga podgrađa u pravom smislu riječi. Međutim, ako se uzme u obzir da je možda riječ o začetcima podgrađa u formiranju (koje se tu i zaustavilo), onda je moguće da doista tako možemo tumačiti i spomenuti navod (kao podgrađe). U svakom slučaju, Sutjeska kao važna odrednica (u ovom slučaju kao župa) i dalje ostaje kao orijentir, što se vidi iz navoda Vratar in Sutischa godine 1452., dok se 1454. godine, u povelji Alfonsa Aragonskoga, navodi:

17 Župa Sutjeska, koja je pripadala plemićkoj obitelji Hranića - Kosača, prostirala se od Vratara do Tođevca, koji je već u drugoj župi (Drinaljevo), tako da su u njezin sastav ulazili i utvrda Vratar i karavanska stanica Tjentište. SEJfudin Isaković, "Tjentište u srednjem vijeku", u: Godišnjak B.Z.K. Preporod, god. XIII., Sarajevo, 2013., str. 356.

18 M. Dinić, "Dubrovačka srednjevekovna karavanska trgovina", str. 130.

19 N. Jorga, Notes et extraits..., str. 338.

20 Isto, str. 408. 
civitate Vratar cum castris et pertinentiis suis. Vratar postaje grad, civitas, sa svojim utvrđenjima i posjedima.

\section{Put Via Drine}

Prije opisa samoga lokaliteta smatramo važnim reći nekoliko riječi o putu Via Drine i njegovoj važnosti za razvoj Vratara. Naime, dva osnovna putna pravca kojima su se kretale karavane i koja su predstavljala glavnu poveznicu Bosne i humskoga prostora s Dubrovnikom, kao najvećim trgovačkim centrom, bila su: Via Chelmi (ili Via Nerente) i Via Drine (ili Via Bosne, ili Via Coze, ili Via Trebigne). ${ }^{21}$ Put Via Drine, koji se dalje nadovezivao na put za Carigrad bio je vjerojatno od velike važnosti za širi prostor. U tom smislu, važna je i funkcija grada Vratara, smještenoga upravo iznad strateški veoma

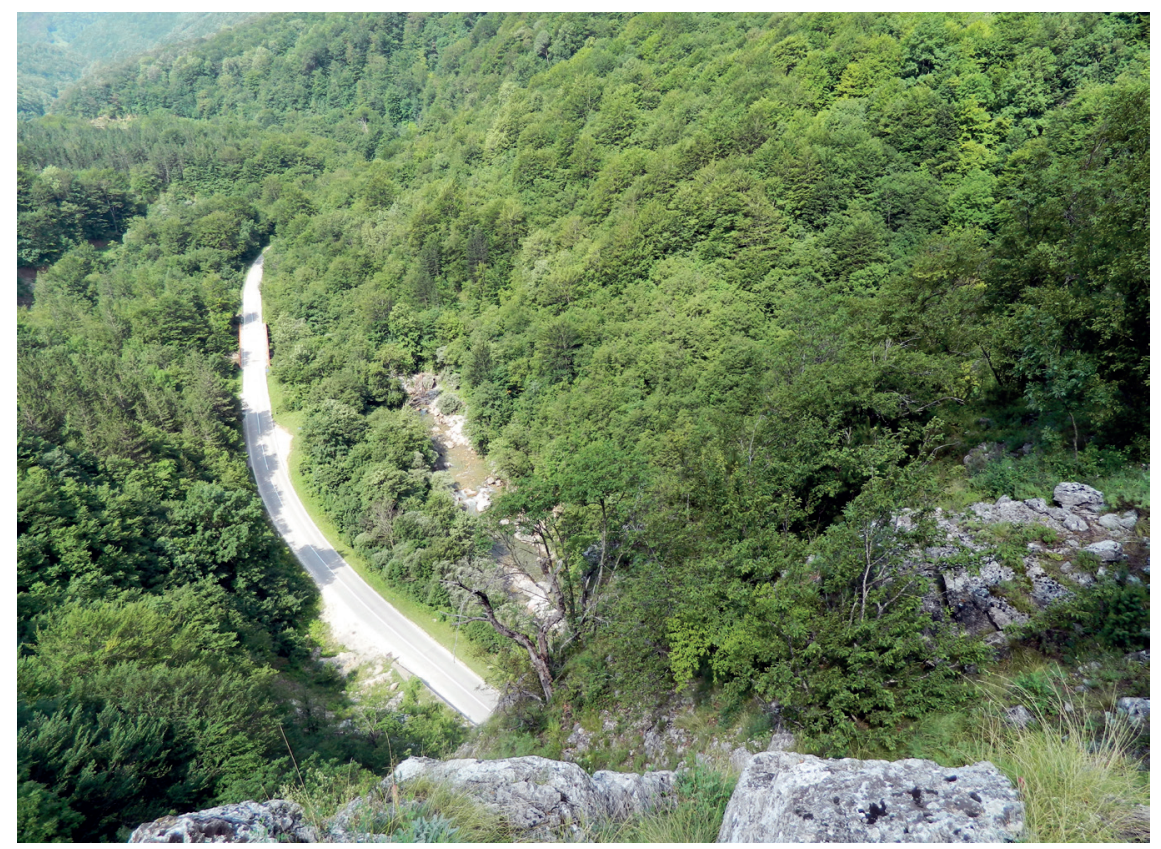

Sl. 1. Pogled s utvrde Vratar na današnju cestu i rijeku Sutjesku (foto: Nina Čuljak)

21 M. Dinić, "Dubrovačka srednjevekovna karavanska trgovina", str. 125; DEsanka KovačEvić, Trgovina u srednjovjekovnoj Bosni, Naučno društvo NR Bosne i Hercegovine, Sarajevo, 1961., str. 158-159; EsAD Kurtović, "Iz historije trebinjskog kraja u srednjem vijeku", u: Godišnjak BZK Preporod, god. XI., Sarajevo, 2011., str. 285. 
važnog prolaza na ovom putu. Upravo u pomno izabranoj lokaciji na "osjetljivom" dijelu puta, koji je bio od iznimnoga značaja u kasnom srednjem vijeku, počiva važnost ovoga grada. Njegov položaj je točno na vrhu klisure gotovo okomito iznad ulaza u Prosječnicu. Odatle je bilo veoma jednostavno blokirati prolaz i zaustaviti čak i veću vojsku s nekolicinom branitelja naoružanih običnim kamenjem. Za razliku od nekih dijelova ovoga, ali i drugih srednjovjekovnih putova koji se mogu izbjeći zaobilaznim stazama, ovaj dio puta je bilo nemoguće zaobići i zbog toga je bio od velike važnosti za ubiranje carina i sl.

Točan pravac puta Via Drine je poznat, budući da se koristio i tijekom novoga vijeka, a danas je zamijenjen modernom asfaltnom cestom. O starom putu, koji se sigurno barem jednim dijelom podudarao sa srednjovjekovnim putom, doznajemo iz nekoliko važnih putopisa. Međutim, o konkretnoj trasi puta nemoguće je govoriti, jer se između dvije poznate "stanice" često moglo put skratiti, ili ciljano zaobići neki dio. Također, prilikom gradnje novih putova, posebice današnje asfaltne ceste, često se odstupalo od trase staroga puta kojoj se s vremenom izgubio trag. Došli smo do zaključka da su jedini dijelovi originalne trase, o kojima uopće možemo govoriti na taj način, zapravo oni koji se nalaze u takvom prirodnom suženju, koje se nije moglo izbjeći. Prilikom naših istraživanja, ustanovili smo da je prostor Prosječnice upravo primjer za to. Djelić izvornoga puta sačuvan je s vanjske strane tunela nazvanog Vratar. Glede pravca kojim je vodio put Via Drine, imamo ga vrlo rano opisanog kod tajnika mletačke vlade, B. Rambertija, koji je s poslanstvom prošao ovim putom tijekom 1533. godine. Naime, krenuvši brodom od Venecije do Dubrovnika, ostatak putovanja do Carigrada nastavio je upravo ovim kopnenim putom. Prema njegovu opisu znamo da je put vodio od Dubrovnika, preko Trebinja, Bileće, Gacka, Čemerna, Tjentišta, Foče i dalje se račvao u nekoliko glavnih smjerova, od kojih se jedan nadovezivao na put za Carigrad. Detaljnije opise ovoga puta, kao i ruševina utvrde grada Vratara, imamo i kod nekoliko putopisaca iz XIX. st. To su primjerice Rośkiewicz (1868. god.) i M. Hoernes (1894. god.), no za potpunu "rekonstrukciju" onoga što su ovi putopisci vidjeli, potrebno je imati na umu da je Rambertijev putopis (i još neki) bio dostupan te nije isključeno da su pojedini "opisi" iz pera putopisaca XIX. st. zapravo prepričavanje podataka iz starijih putopisa, ili pak bilježenje predaja i legendi mještana. U tom smislu ipak nam je najznačajniji opis B. Rambertija, koji je najstariji nama poznati opis pa samim tim i najzanimljiviji. Prema njegovu putopisu putovanje je išlo od dubrovačkih vrata Ploče, preko Srđa, Brgata, prema Carini, 
potom se išlo "pustom kamenitom gorom" u dolinu Trebišnjice te su nakon 16 milja stigli u Trebinje. Kod Trebinja su prešli Trebišnjicu i nakon 20 milja stigli u Rudine, prošavši djelomice porušeni gradić Cluaz, dospjeli su u 28 milja udaljeno selište Curita. Nakon što su prošli Cernicu, za 25 milja došli su u Vrbu. Nadalje za 24 milje stigli su u Predio, prošavši gorsko ždrijelo "na kojem se s obje strane dižu dvie tvrđice, od kojih je jedna porušena, a druga se iztiče nad stienom i zove se Vratac".22 Nadalje se navodi "tvrđice su sječene i zidane na samoj gori, a k njim se dolazi stazom, samo jednoj osobi pristupnom, a moglo bi je dvadeset ljudi lako braniti kamenjem proti kakovoj mu drago vojsci". ${ }^{23}$ Nakon ovoga zabilježen je netočan podatak da pod utvrdama teče rukav vode, pod imenom Drine. Nakon 29 milja dospjeli su u Orach, pa u Foču. ${ }^{24}$ Kada pokušamo pratiti opisanu dionicu puta, uviđamo da i sam Ramberti navodi poneki podatak koji očito nije vidio, nego ga je doznao na putu. Tako primjerice spominje da je prošao djelomice porušeni gradić Ključ (kod Gacka), a kada doista terenski obiđemo taj kraj, kao što smo napravili, postaje nam jasno da je za dolazak pod Ključ potrebno dobro se udaljiti od glavnoga pravca Via Drine. Svakako se može reći da Ključ gravitira ovom putu, ali on je posve sigurno bio na većoj udaljenosti od njega.

Svakako nam je najzanimljiviji opis dviju "tvrđica", od kojih je jedna već u njegovo vrijeme uništena, dok se druga i dalje vidi te mu je pokazana kao Vratac. Ono što je nama osobno zanimljivo u ovom navodu jest činjenica da se spominju dvije utvrde, od kojih je jedna porušena, a druga se vidi na stijeni. Postavlja se pitanje koliko je uopće bilo moguće iz južnoga pravca uočiti pravu utvrdu Vratar koja se očito još u dobroj mjeri očuvala u to vrijeme, a kamoli tu porušenu utvrdu nasuprot njoj. Na tragu smo promišljanja da je ovdje možda riječ o nekim starijim ruševinama (moguće neke crkve) na obližnjem prostoru, koja je kod lokalnoga pučanstva rodila ideju o utvrđenju na obje strane klanca. Također u mnogo kasnijem opisu Rośkiewicza stoji: "one dvije tvrđice biti će ondje ležale, gdje se stiene Sutjeskine doline na 50 stopa primiču, gdje se još danas vide tragovi, na desnom briegu Sutjeske, na uzvišenom pećinastom ravnaku, stare su ruševine (Gradina na karti), o kojih se priča, da su posljednji ostanci gradića kr. Stjepana, a naproti, na kuku Sedla, da je njegda bila crkvica

22 P. Matković, "Putovanje po balkanskom poluotoku XVI vieka...", str. 210.

23 Isto, str. 210.

24 Isto, str. 209-211. 
(Crkvina na karti), a oboje da je bilo mostom skopčano. Ta je pako točka danas poznata po imenu Prosječenice". ${ }^{25}$ Upravo ovaj opis dade naslutiti da se predaja o postojanju neke stare crkve na tom prostoru uplela s pričom o dvije utvrde na dvije strane klanca.

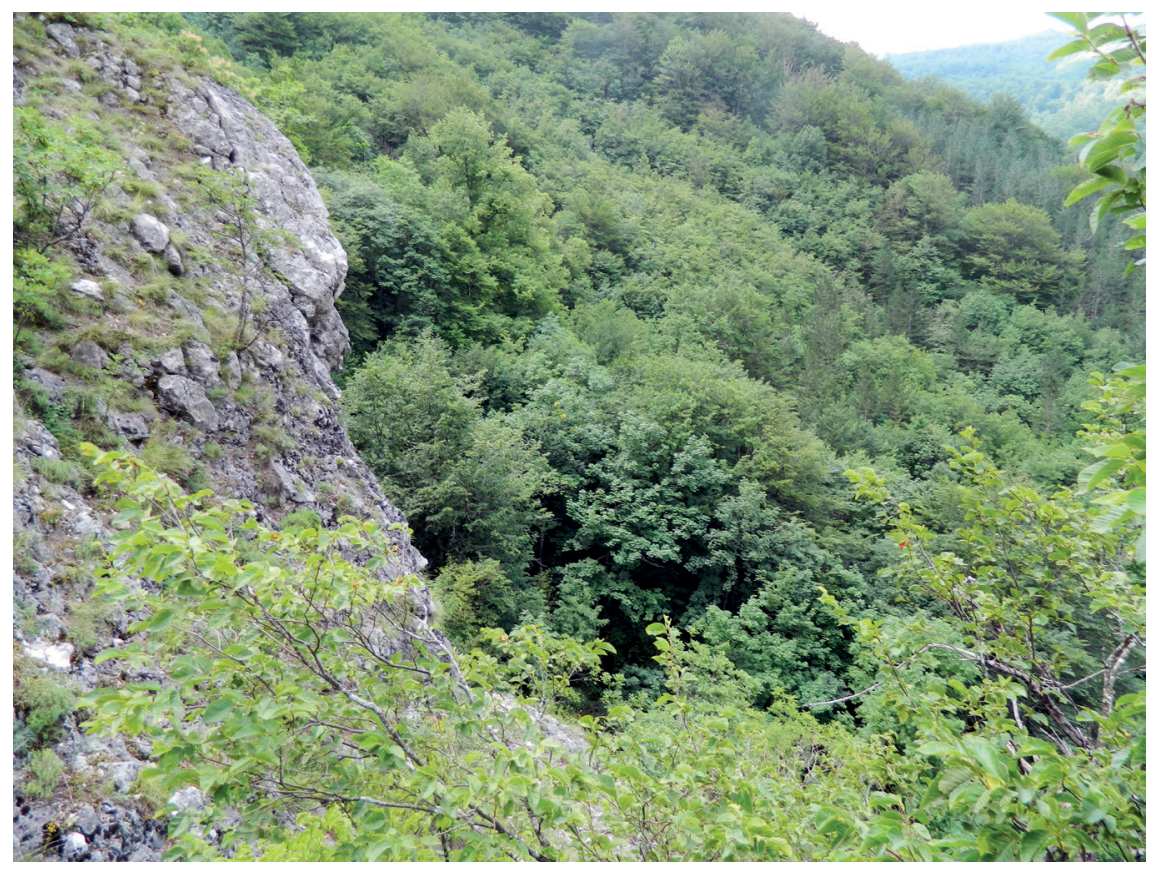

S1. 2 Pogled na pristupni put do Vratara, danas potpuno zarastao u šumu

(foto: Nina Čuljak)

Važno je naglasiti da su srednjovjekovni putovi (u literaturi nalazimo i prijevod - drumovi, koji je možda i adekvatniji) uglavnom obične staze, pogodne za kretanje pješaka i natovarenih konja, ponegdje su bili prošireni, ili su bili kaldrme (ovo je vjerojatnije antičko nasljeđe, a moguće i turske i kasnije nadogradnje). ${ }^{26} \mathrm{U}$ svakom slučaju, daleko su od reprezentativnosti onoga što se u moderno vrijeme podrazumijeva pod tim pojmom. No, bez obzira na njihovu skromnost, služili su svrsi i stoljećima bili osnovne žile kucavice šire regije, na koji-

\section{Isto, str. 212.}

26 Lijep primjer su rubnici kaldrme koja vodi na Lipetu i Kulu, na putu Via Chel$m i$, koje smo također zabilježili na našim terenskim rekognosciranjima. Budući da se i na tom dijelu vrše modernizacije, očito je da će i ovaj prekrasan dio prastaroga puta kroza samo srce Hercegovine, biti uskoro uništen gradnjom asfaltne ceste. 
ma je počivao privredni rast i razvoj. Svakako, jedno važno polazište za te procese bilo je rudno bogatstvo Bosne koje je posvjedočeno od prapovijesti a posebice od antičkoga vremena, predstavljalo privlačni izvor zarade svim susjednim oblastima, pa samim tim i putna povezanost dobiva jednu dodatnu svrhu. Na važnim točkama putova javljaju se karavanske stanice, trgovi, utvrde, ili pravi gradovi, u čijim se podgrađima ${ }^{27}$ rađaju zametci nekih kasnijih naselja. Vladari i velikaši ubiru carine i akumuliraju bogatstvo, jednako kao i trgovci i zanatlije. To je cijeli proces koji je pokrenut i koji je opstao upravo zahvaljujući ovom nizu: razvoju rudarstva - intenziviranju trgovine - ubiranju carina - izgradnji utvrda koje su bile važni kontrolni punktovi, ali često i prave rezidencije vladara odnosno velikaša. Također, u to vrijeme putove treba doživljavati (u smislu konkretnih trasa) dosta fluidno. Naime, pojedini su se dijelovi mogli ciljano zaobići alternativnom stazom, kako bi se eventualno zaobišla neka carina, ali čini se da to i nije bila opća praksa - jer su posve sigurno oni koji su carine ubirali to pokušavali spriječiti. Na putu Via Drine može se samo zamisliti kolika je morala biti važnost utvrde Vratar, jer se nalazila na takvu mjestu, gdje doslovce nije postojala mogućnost "zaobilaska", ${ }^{28}$ odnosno alternativne staze. Kroz klanac Sutjeske se naprosto moralo proći, i stoga smo došli do zaključka da ovdje možemo govoriti o jednom od rijetkih slučajeva gdje baš precizno možemo ubicirati jedan djelić srednjovjekovnoga puta. A to je upravo makadamski prolaz točno ispod same utvrde. O napuštanju Vratara u periodu prije 1533. godine imamo podatak kod autora koji su relevantni za tu problematiku, naime riječ je o Hamdiji Kreševljakoviću i Hamdiji Kapidžiću, koji u radu o starim hercegovačkim gradovima pretpostavljaju da "u njemu Turci nisu držali svoje posade". ${ }^{29}$

27 Pod gradovima koji pripadaju slivu rijeke Drine i njezinih pritoka, gotovo se redovito oblikuju podgrađa i to tijekom 20 -ih god. XV. st., pa tako i Podvratar. Ovo svakako govori o jednom uzletu urbanizacije (u formiranju), a sve u svezi s privrednim usponom cijele oblasti. Više kod: Desanka KovačEvić-KoJIć, Gradski život u Srbiji i Bosni (XIV-XV), Istorijski institut, Beograd, 2007., str. 141.

28 Zbog ovoga su suvišna bila upozorenja Dubrovčana Stjepanu Vukčiću Kosači kako carina poput te u Sutjesci čini štetu Dubrovčanima, iako je ne plaćaju oni, nego Vlasi te kako će Vlasi i drugi (očito se misli na ponosnike) napustiti taj put. O tome: S. Ćirković, Herceg Stefan Vukčić - Kosača i njegovo doba, str. 23.

29 H. KREŠEVlJAKović - H. KAPIDŽIć, "Stari hercegovački gradovi", str. 21. 


\section{Grad $^{30}$ Vratar - položaj lokaliteta}

"Ova vrata su nekoć imala svog vratara"31 (Moritz Hoernes)

Lokalitet Vratar (Sutiska) ${ }^{32}$ nalazi se kod Suhe, ${ }^{33}$ oko $30 \mathrm{~km}$ južno od Foče. Smješten je iznad najvećega suženja klanca rijeke Sutjeske, koje-

$30 \mathrm{U}$ znanstvenoj literaturi postoje brojni osvrti na pitanje nazivlja u srednjovjekovnoj fortifikacijskoj arhitekturi. U domaćoj literaturi je veoma ustaljen termin grad, ili "stari grad" još od Ć. Truhelke koji i u ovom radu koristimo. O tome vidjeti: ĆIro TruHelKa, Naši gradovi, opis najljepših sredovječnih gradova Bosne i Hercegovine, Sarajevo, 1904. Dodatno se koristimo pojašnjenjem da je ta riječ "poput castruma značila i utvrđeno naselje i feudalni grad". Usp. AnA DeAnović, "Glosar naziva u upotrebi srednjovjekovnog i renesansnog vojnog graditeljstva u Hrvatskoj", u: Rad Jugoslavenske akademije znanosti i umjetnosti, knj. 381, Zagreb, 1978., str. 37. Također se koristimo i tumačenjem da je "grad staroslavenska imenica kojom Slaveni po doseljenju nazivaju utvrđenja bez razlike jesu li ona organizirana naselja uz utvrdu, ili sama utvrda (tvrđava)". Usp. BožIDAR ZARKović, Trgovi i urbanizacija Srbije krajem srednjeg i početkom novog veka, doktorska disertacija, Beograd, 2012., str. 60. Pitanje je naravno razgraničenja pojmova utvrde i grada, no smatramo da poradi visokoga stupnja neistraženosti naših srednjovjekovnih gradova/utvrda, doista ne možemo još primijeniti neki konkretan sustav raščlambe. Iako je ovdje doista riječ (u slučaju Vratara) o iznimno skromnim ostatcima arhitekture, ipak, poradi navoda u izvorima, u kojima se ovaj lokalitet spominje u znamenitim poveljama kao: Vatrato, Sucisti, castello con lo contato (1444. godine), potom kao castrum Bratal cum omnibus pertinentiis suis (1448. godine), te kao civitas (civitate Vratar cum castris et pertinentiis suis (1454. godine), ne možemo ga ne smatrati gradom u srednjovjekovnom značenju, jer je on to očito bio.

31 Moritz Hoernes, Dinarische Wanderungen: Cultur und Landschaftsbilder aus Bosnien und der Hercegovina, Wien, 1894., str. 207.

32 Jireček spominje ovu utvrdu kao "znanu pod imenom Vratar u Sutisci, ili samo Sutiska". C. JIREČEK, Die Handelsstrassen und Bergwerke..., str. 75. U Arheološkom leksikonu Bosne i Hercegovine lokalitet je upisan kao Vratar (Sutiska), Suha, (u Općini) Foča. O tome: "Vratar (Sutiska)", u: Arheološki leksikon Bosne i Hercegovine, sv. III., str. 131. Ovi navodi svoje uporište imaju u povijesnim izvorima, u kojima se lokalitet spominje kao Vratar u Sutjesci (ili Sutisci), gdje je Sutjeska/Sutiska srednjovjekovna župa, ali i mjesto, odnosno dio uskog kanjona rijeke Sutjeske. Jedan od izvornih navoda je in Sutischa, a odnosi se na podatak iz 1436. god., u kojem se spominje nova carina in Sutischa, a također zanimljiv je podatak iz dubrovačkoga pisma Stjepanu Vukčiću (445. god.) u kojem se Dubrovčani žale na pljačku trgovaca sotto Sutischa (pod Sutjeskom), što je veoma značajan podatak, jer osim činjenice da se navodi gradsko podgrađe, koje nam svjedoči o jednom daljnjem stupnju razvoja mjesta ka gradskom naselju, ovdje imamo i nazivanje (očito središta župe) samim imenom župe. N. JorgA, Notes et extraits..., str. 338, 408.

33 Nakon obilaska terena mišljenja smo da bi najtočniji bio navod koji od G. Škrivanića prenosi M. Premović: smještaj između Ninkovića i Suhe. O tome: 
ga oblikuju obronci planinskih masiva Volujaka i Zelengore, na samoj geografskoj granici Hercegovine prema Bosni. Danas se na tom mjestu (točno ispod utvrde) nalazi tunel također nazvan Vratar te je taj važni kasnosrednjovjekovni lokalitet barem na takav način obilježen. Naime, druge oznake za ovaj lokalitet na terenu (ni ispod njega) nema. ${ }^{34}$ Važnost lokaliteta i svakako razlog njegovu postojanju počiva u činjenici da se nalazi na veoma "osjetljivom" dijelu važnoga srednjovjekovnog puta Via Drine, ${ }^{35}$ koji je iz Dubrovnika vodio prema Foči i dalje u unutrašnjost. Naime, riječ je o smještaju u iznimno uskom klancu rijeke Sutjeske, koji se na spomenutom putu nije mogao zaobići.

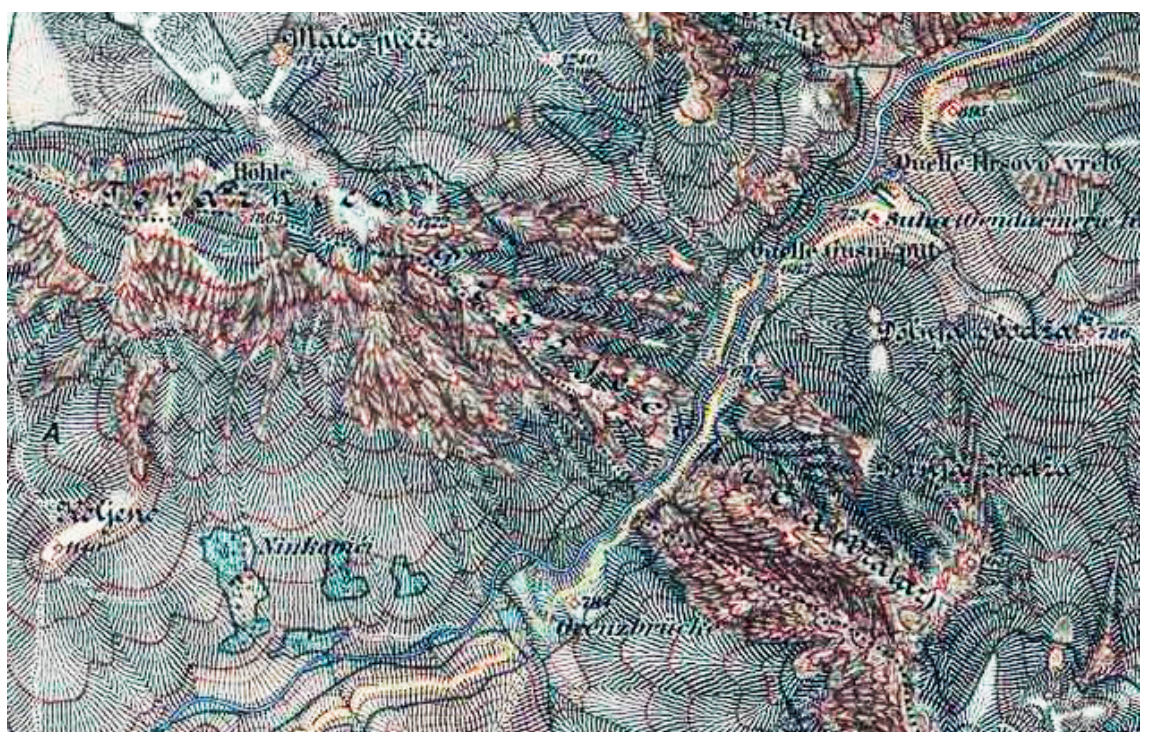

S1. 3. Prikaz upisanoga toponima "Prosječenica (Vratar)" na austro-ugarskoj karti iz Trećeg vojnog premjera (1869. - 1887.)

Marjan Premović, Srednje i donje Polimlje i gornje Podrinje u srednjem veku, doktorska disertacija, Beograd, str. 57. Ovdje je također veoma važno napomenuti da se u Ninkovićima nalazi i jedna nekropola sa stećcima, što je i naznačeno na Karti Nacionalnog parka Sutjeska.

34 Lokalitet je jedino označen kao takav, pod nazivom Vratac, na Karti Nacionalnoga parka Sutjeska, na Tjentištu.

35 Ovaj put je vodio prema prostoru srednjovjekovne Srbije, ali i dalje na carigradski drum, te je bio od međunarodne važnosti. U izvorima se navodi kao "via Drine", i "via Foče". Foča je, naime, još od 1368. god. poznata u izvorima, i bila je važan trg. Župa Sutjeska gravitira oblasti Srednjeg Podrinja i poznata je po stočarstvu, trgovini i pčelarstvu u kasnom srednjem vijeku. Objavljeni su brojni arhivski podatci koji svjedoče o tome, npr. o izvozu kože, voska i sl. D. KoJIć Kovačević - V. Palavestra - Z. Kajmaković, "Drina u doba Kosača", str. 110-125. 
Upravo prirodno suženje uz obalu rijeke Sutjeske, moćno je zaštićeno oštrim klisurama, koje se gotovo vertikalno spuštaju na put i obale rijeke. Prolaz ispod utvrde Vratar na ovom mjestu bio je moguć samo relativno uskim puteljkom na desnoj obali Sutjeske. On se pak pruža s vanjske strane današnjega tunela, koji je taj prolaz artificijelno proširio te mu olakšao prohodnost. Stoljećima prije njega korišten je upravo uski makadamski put uz samu rijeku. Upravo zbog ovakva smještaja došli smo do spoznaje da se ovdje doista može govoriti o dijelu (iako veoma malom) izvorne trase famoznoga srednjovjekovnog Drinskog puta.

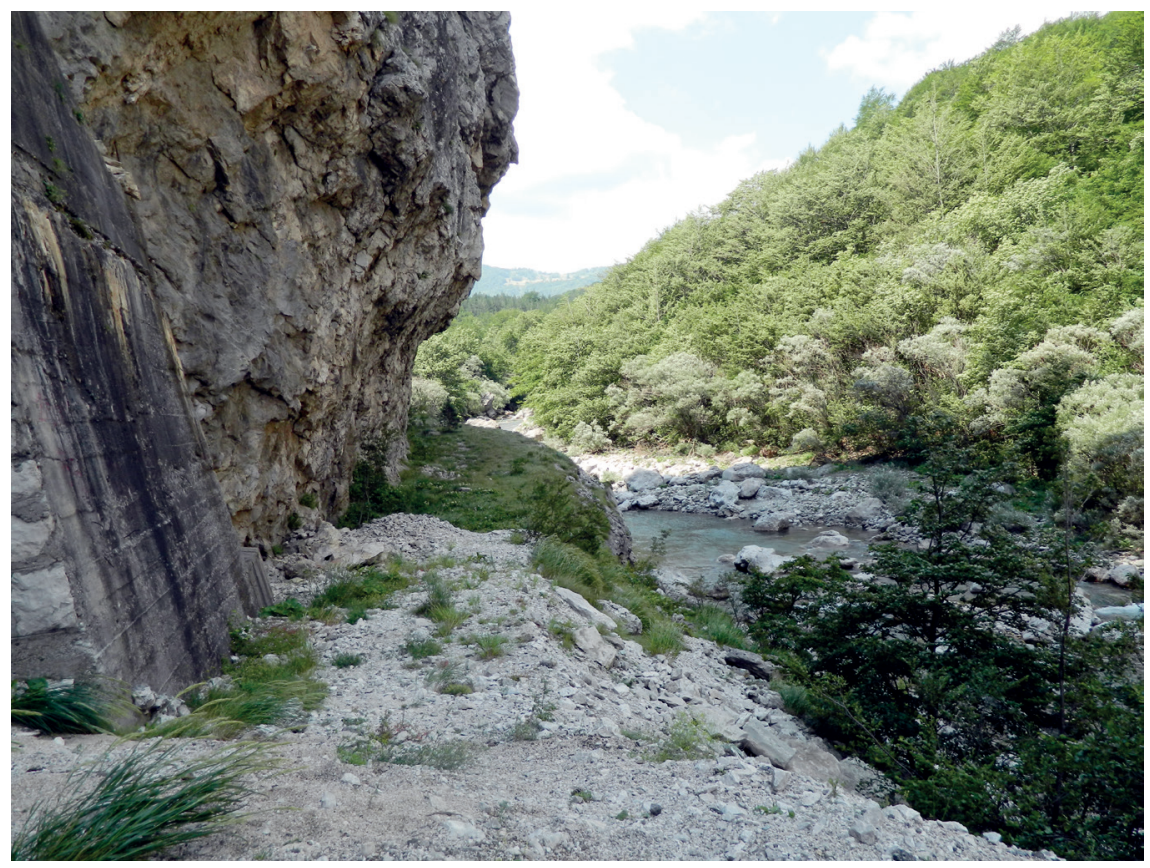

S1. 4. Dio puta Via Drine u vidu djelomice usječenoga polusvoda u stijeni (foto: Nina Čuljak)

U ovim promišljanjima i zaključcima pomogli su nam navodi iz izvora, ali i mnogo više prikaz ove lokacije na staroj austro-ugarskoj fotografiji Raimunda Stillfrieda von Rathenitza iz 1890. godine, naziva Talsperre bei Sucha. Možemo konstatirati da se spomenuti fotografski prikaz podudara s opisom istoga prolaza zabilježenoga kod Jirečeka ${ }^{36}$ te se također podudara sa situacijom koju smo zatekli na 
terenu. Naime, Jireček je konstatirao da se ruševine koje B. Ramber$\mathrm{ti}^{37}$ spominje nalaze "u blizini mjesta gdje je po svoj prilici u vrlo staro doba na maloj dužini usječen put u stijeni, u vidu poluzasvedenog hodnika". ${ }^{38}$ B. Ramberti pak navodi da je na tom mjestu vidio dva castelleti-a (s obje strane klanca), od kojih je jedan već bio uništen, a drugi je bio vidljiv te mu je pokazan kao Vratac, ${ }^{39}$ uz opasku kako

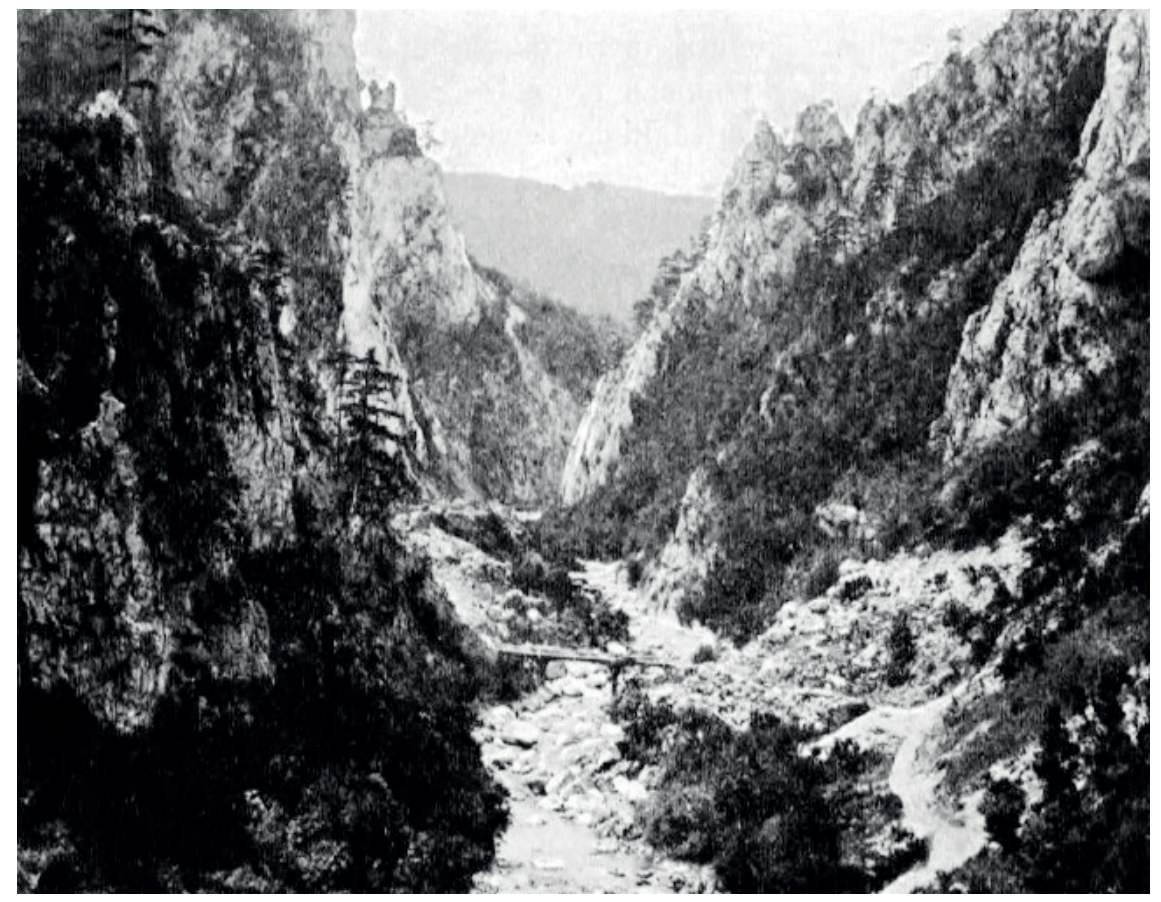

Sl. 5. Put kroz klanac Sutjeske (prema: Henrik Renner, Herceg - Bosnom uzduž $i$ poprijeko, Mitrovica, 1900., str. 342)

37 Benedetto Ramberti, tajnik mletačke vlade i učeni pisac iz XVI. st., koji je s poslanstvom prošao ovuda 1533. god., o tome je ostavio podatke u svom putopisu koji nam donosi P. Matković. P. Matković, "Putovanje po balkanskom poluotoku XVI vieka...", str. 204.

38 C. JIREČEK, Die Handelsstrassen und Bergwerke..., str. 76. Opis nalazimo i kod: Johann Rośkiewicz, Studien über Bosnien und die Herzegovina, Leipzig Wien, 1868., str. 113. Tu piše: "Der Weg ist hier blos 2 Fuss breit in Felsen gehauen, die Grundflächen desselben so glatt und zum Wasserlauf der Sutinska so abschüssig, dass man bei niederm Wasserstande es vorzieht, durch das Flussbett zu reiten."

39 Ovaj podatak je donio određene nejasnoće, no postoji mogućnost da je ovaj dio klanca bio nazivan tim imenom nevezano uz utvrdu Vratar, koja je po sličnoj 
je herceg Stjepan tu imao stražu, tako da nitko nije mogao proći bez plaćanja carine.

Također donosi podatak da su utvrde bile od samih stijena i da je do njih vodila staza kojom je mogla normalno proći samo jedna osoba,

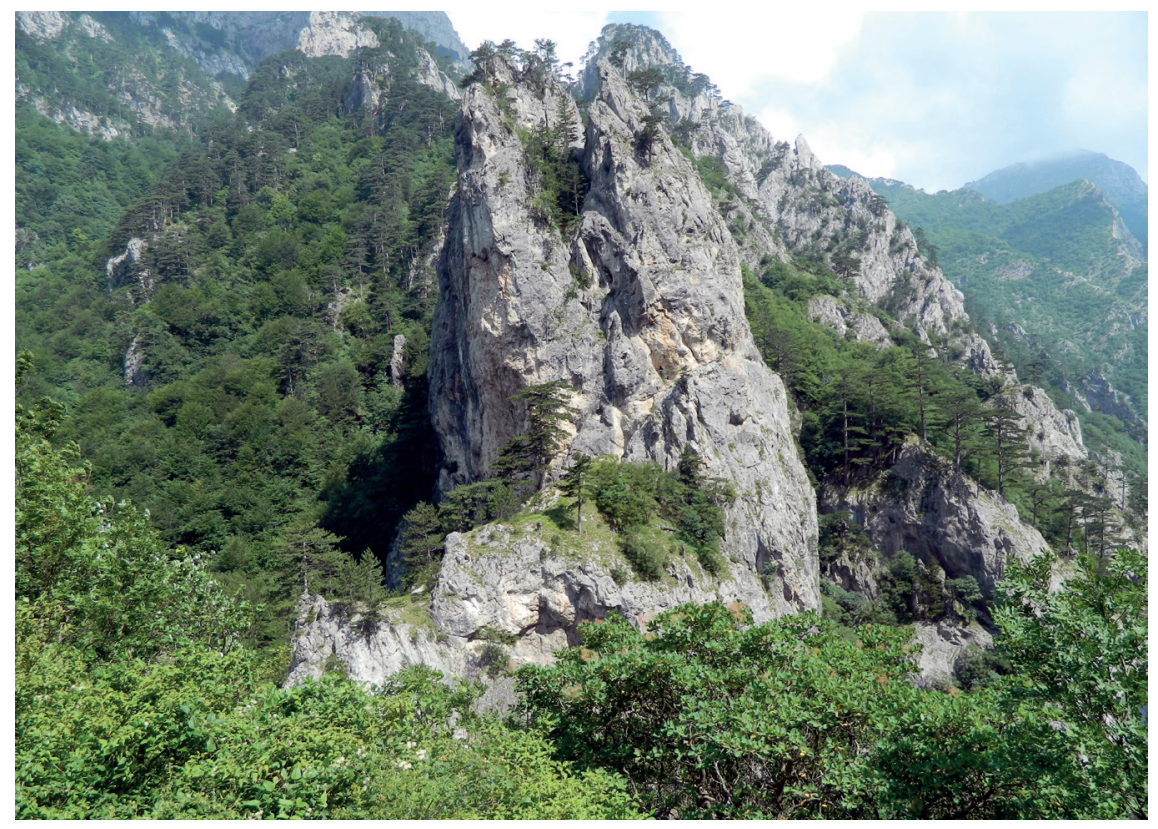

S1. 6. Mala zaravan točno nasuprot ruševina utvrde - slikano s utvrde (foto: Nina Čuljak)

geografskoj logici dobila to ime. Zanimljivo je ovdje spomenuti da je i na jednoj od karata iz XVI. st., na kojoj je prikazana i današnja Bosna i Hercegovina (onoj J. Bussemachera iz 1592. god.) Vratar ucrtan kao Vrotaz, što može biti izravno u svezi s dostupnim putopisima, poput Rambertijevog. Naime, doista se ne može pouzdati u karte ovoga stoljeća (za prostor Hercegovine), zbog preslaboga interesa tadašnjih kartografa za naš prostor i činjenice da su se često preuzimale netočne ubikacije i sl. Više o tomu može se doznati u relevantnoj literaturi. Kartu vidjeti u: Mirкo Alilović, Hercegovina na kartama i planovima, Velika Gorica, 2015., str. 191. Ovdje je bitno spomenuti i jedan podatak koji navodi Matković, citirajući svoga suvremenika, očito upućenoga u lokalne prilike: "Ulaz u klanac Sutjeske, od Graba jedan sat niže, zove se Vratac i vide se na desnoj strani na planini pod Volujakom razvaline tvrđice Hercega Stjepana, sproću nje srušena crkvica na lijevoj strani na rebru Zelengore. Tu je sutjeska najuža, izgleda, kao da će ove dvije planine i razvaline rukovati. Priča se, da su tu bili pripeti gvozdeni lanci od tvrđice do crkvice, u koju je Herceg prelazio na službu. Tu se za njegova vremena plaćala prolaznina." P. MAтković, "Putovanje po balkanskom poluotoku XVI vieka...", str. 213. 
te da je ove utvrde moglo od cijele vojske lako obraniti svega 20 ljudi naoružanih samo kamenjem. ${ }^{40}$ Lijep primjer koji dade naslutiti kako je taj put klancem Sutjeske doista mogao izgledati u srednjem vijeku, ali i koliko je bio opasan, vidimo na slici koju donosi $H$. Renner, u svom putopisu Herceg - Bosnom uzduž i poprijeko, u kojemu se navodi da je ovaj put kroz klanac Sutjeske "staza za pjesnike i prijatelje prirode", ${ }^{41}$ kao i to da ga u to vrijeme koriste samo domaći ljudi.

U predaji lokalnoga pučanstva i dalje živi priča da su tu nekad postojali željezni obruči, odnosno lanci koji su blokirali put kroz Prosječnicu. To je priča koja se očito provlači još od upisa Des Hayesa (iz 1621. godine), što doznajemo od Jirečeka. ${ }^{42} \mathrm{Na}$ terenu su nam pokazane neke rupe u stijeni, vrlo nisko iznad površine rijeke. Naravno da metalnim obručima nema traga, ali moramo priznati da rupe u stijeni doista djeluju kao nešto artificijelno, tako da nije isključeno da su nekad korištene kao neki vid utora. Teško je tu razlučiti činjenice od predaje i legendi. Ukoliko je tijekom srednjega vijeka tu postojao željezni lanac za blokiranje puta, to bi svakako ukazivalo na neki niži smještaj istoga.

Prema drugim putopiscima iz kasnijega vremena ti lanci su povezivali dvije utvrde grada na dvije obale, ili grad i crkvu, a to bi značilo neki vid lančanoga mosta koji bi povezivao utvrdu sa stijenom na drugoj strani rijeke. Budući da smo osobno pregledali teren i ostatke utvrde, možemo konstatirati da doista postoji jedna mala zaravan na nasuprotnoj stijeni, koja je otprilike na istoj razini kao položaj ruševina Vratara. Zumiranjem toga dijela posve je jasno da je to vrlo skučeni prostor, na vrletima krajnjih obronaka Zelengore, i da bi smještaj bilo čega na toj strani bio veoma neprikladan, no ne i nemoguć. Sam položaj ruševina Vratara, usprkos svojoj teškoj pristupačnosti, u potpunosti je logičan, jer na obje strane pruža doslovce savršenu vizualnu kontrolu nad samim putom. Kada stojimo na rubu utvrde (iznad ulaza u današnji tunel) - stojimo de facto okomito iznad puta. A to je doista takva strateški pomno birana pozicija, bez premca.

40 C. JiRečEK, Die Handelsstrassen und Bergwerke..., str. 76.

41 Henrik Renner, Herceg - Bosnom uzduž i poprijeko, Mitrovica, 1900., str. 341.

42 Jireček također navodi kako je Des Hayes (1621. god.) dobio informaciju da se taj prolaz u kršćansko vrijeme zatvarao željeznim lancem. Moguće da je od tada ostala predaja o obručima na obali Sutjeske. C. JirečEk, Die Handelsstrassen und Bergwerke..., str. 76. 


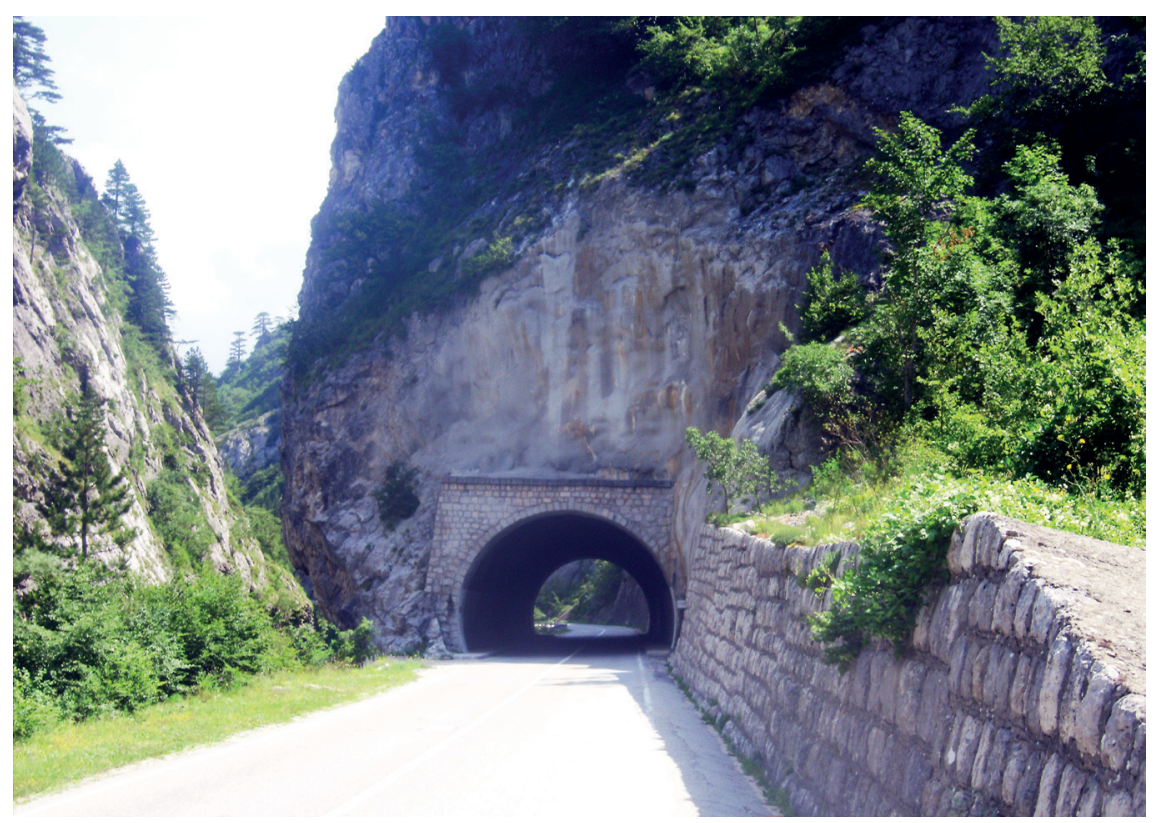

S1. 7. Pogled prema Prosječnici uz današnji tunel Vratar (foto: Dijana Pinjuh)

Stoga uopće ne čudi podatak o lakoći obrane grada, koji se provlači stoljećima u predaji i literaturi.

Sam najuži prolaz kroz klanac naziva se Prosječnica. ${ }^{43}$ On promatran s određene udaljenosti doista tako i izgleda, kao neki uzan prolaz, ili

43 "Wohl aber sind noch am rechten Ufer, auf hochsituirten Felsterrassen, Mauerspuren zu erblicken, welche die Sage als die letzten Reste einer vom König Stephan erbauten Burg bezeichnet. Gegenüber, auf einem Felsvorsprunge des Sedlo, soll auch zu jener Zeit eine kleine Kapelle gestanden haben, und Burg und Kapelle (nach der Sage) durch eine Brücke verbunden gewesen sein. Dieser Punkt ist gegenwärtig unter dem Namen Prosćjenica (d. h. durchschnittene oder durchsägte Strecke) bekannt." J. Rośkiewicz, Studien über Bosnien und die Herzegovina, str. 114. Također, Prosječnica se spominje i kod M. Hoernesa koji uz opise veličanstvene prirode toga dijela svijeta, spominje da se ostatci jednoga utvrđenja još mogu pronaći na jednom obronku Volujka, dok se utvrda na lijevoj obali nalazi na rubu stršeće litice te da je tu bila nekoć carinarnica hercega Stjepana. Nakon toga navodi opis kako se prolaz moglo obraniti sa samo 20 branitelja, što je očito preuzeo od Jirečeka, kao i podatak o postojanju željeznoga lanca. Jireček je pak taj podatak o lancu preuzeo od Des Hayesa (koji je 1621. god. čuo tu predaju "iz kršćanskog vremena"). M. HoERNES, Dinarische Wanderungen: Cultur und Landschaftsbilder aus Bosnien und der Hercegovina, str. 207. 
vrata. U neposrednoj blizini nešto južnije nalaze se ruševine nekih zidova, koje nam u početku i nisu bile posebno zanimljive, jer nam je pažnja bila usredotočena na samu utvrdu iznad. Kasnije, prilikom učestaloga nailaska na spomen utvrda na obje strane klanca, došli smo na razmišljanje da je možda tu riječ o obrušenom dijelu druge utvrde (ili crkve) koja se spominjala u starim putopisima. Činjenica jest da je poprilično velik komad zida doslovce skliznuo, ili se urušio odnekud, no isto tako - njegova originalna pozicija nije mogla biti previše visinski udaljena, jer bi se u protivnom potpuno raspao, bez obzira na granjem obraslo kamenje i sve ono što je postalo neki vid prirodnoga serklaža koji je očito tu konstrukciju održao u komadu.

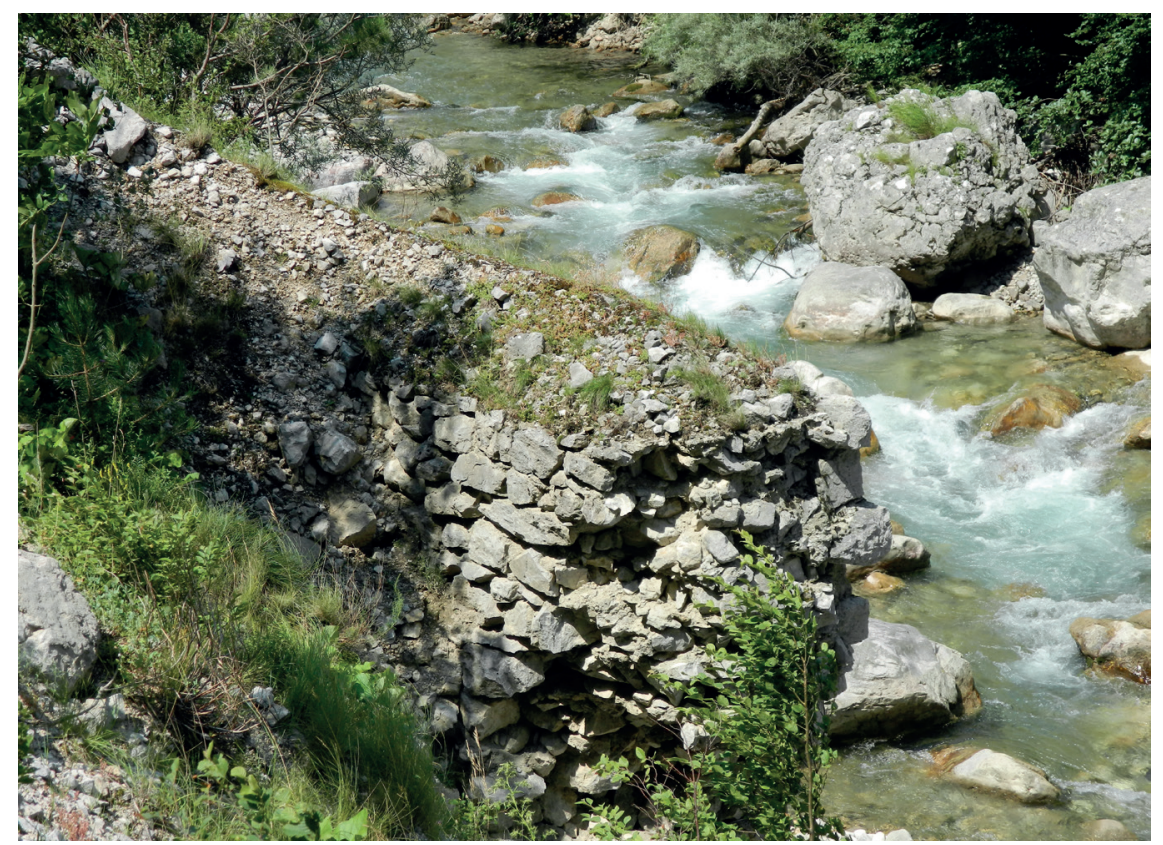

Sl. 8. Skliznuti dio nekoga zida uza samu rijeku (foto: Nina Čuljak)

Njegova današnja pozicija u potpunosti je nepravilna i nemoguće je da je originalna, tako da je posve sigurno riječ o pomijeranju, samo pitanje je od kuda. Inače, na samoj utvrdi evidentna su velika klizišta, koja su svakako dodatno uništila lokalitet. U načelu, podatak o postojanju "žandarske stanice", koji smo dobili od mještana, odvratila je našu pažnju od toga skliznutog dijela zida. No zid je solidno zidan, i tu bi se detaljnijim pregledom moglo doći do nekih novih promišljanja. No, ako se ponovo vratimo na izvorni opis kod B. Ram- 
bertija, dolazimo do toga da su dotične utvrde bile otprilike na istoj visini, pa je prema tome nemoguće da je ovaj skliznuti dio zida - dio te konstrukcije, posebice zbog toga što je na desnoj obali. No pitanje je, ako je ta druga utvrda (moguća crkva prema kasnijim navodima) bila urušena već u Rambertijevo vrijeme, nije li vjerojatno da se priča o postojanju druge, srušene utvrde, spojila s predajom o postojanju neke crkve na tom prostoru (ne nužno na istom dijelu), tako da se one počinju poistovjećivati. Budući da su na starim mapama ostali pribilježeni toponimi Crkvina i Gradina, velika je vjerojatnost da je na tom prostoru nekoć i bila crkva, ali je pitanje ima li ona ikakve veze konkretno s drugom srušenom utvrdom, ili je postojala na tom prostoru, ali na drugom mjestu. To ćemo možda saznati ukoliko se na tom području provedu arheološka iskopavanja.

Inače, kada se promatra cijeli ovaj kanjon i okolica, može se reći da je to veoma uzak prostor, stoga ne čudi činjenica što nikada nije došlo do formiranja pravoga gradskog naselja, iako je u vrijeme Stjepana Vukčića Kosače bilo naznaka o daljnjem razvoju naselja. Jedino nešto veće proširenje je na prostoru Suhe, dok se za ipak malo udaljenije Tjentište može reći da je imalo doista optimalne uvjete za formiranje pravoga naselja, s dovoljno ravničarskoga prostora, blizinom rijeke, ali ponajprije zbog toga što je predstavljalo karavansku stanicu na važnom putu. Ta tradicija se nekako protegla i na novi vijek, kada je ovaj lokalitet postao izletište s hotelom i prenoćištima u sklopu Nacionalnoga parka Sutjeske. Kasnosrednjovjekovno Tjentište je svakako bilo u tom smislu značajno, a tadašnje svratište - kuću (domus) imao je i Stjepan Vukčić Kosača. ${ }^{44}$ Tu se vjerojatno radilo o trgu u formiranju, jer se u izvorima spominje i postojanje carinika i lokalnoga kneza u Tjentištu. ${ }^{45}$ Tjentište se naime, kao karavanska stanica, formiralo na putu Via Drina, tijekom 40 -ih godina XV. st., ${ }^{46}$ te je za razliku od nešto udaljenije Cernice tek tada počelo poprimati karakter stalnoga naselja. Upravo je svoj naziv Tjentište dobilo po

44 M. Dinić, "Dubrovačka srednjevekovna karavanska trgovina", str. 135-136. Od 40-ih godina XV. st. u Tjentištu je još jedna u nizu karavanskih stanica. Tu se nalazila i kuća hercega Stjepana i jedan konak. Hercegova majka Katarina ubirala je carinu koja je tu bila uspostavljena. D. KovačEvić-KoJıć, Gradski život u Srbiji i Bosni (XIV-XV), str. 148.

45 S. Isaković, "Tjentište u srednjem vijeku", str. 353, 357.

46 D. Kojić Kovačević - V. Palavestra - Z. Kajmaković, "Drina u doba Kosača", str. 120 . 
šatorima ${ }^{47}$ pod kojima se prenoćivalo na putovanju, a godine 1450 . spominje se carina de Tiutiste. ${ }^{48}$

\section{Grad Vratar - ostatci ostataka}

$\mathrm{Na}$ obroncima Volujka nalaze se skromni građevni ostatci srednjovjekovnoga grada Vratara. Lokalitet je savršeno strateški pozicioniran točno na stijeni koja se vertikalno uzdiže uz Prosječnicu, te na taj način postoji mogućnost kontrole puta i prema jugu i prema sjeveru. U blizini nema naselja.

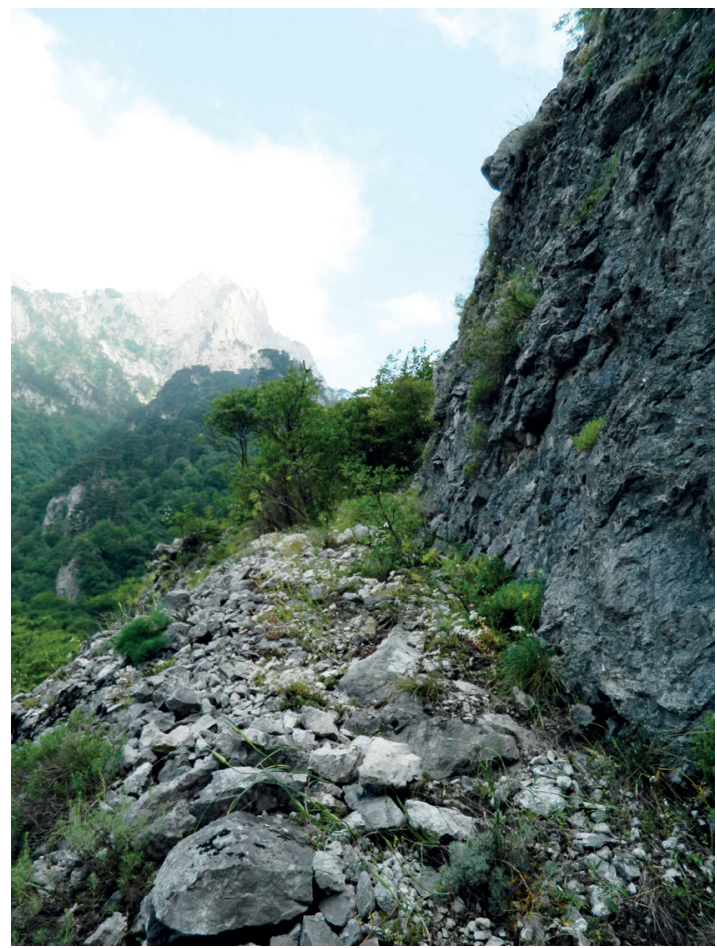

S1. 9. Dio izvorne staze pred sam izlazak na grad (foto: Nina Čuljak)

47 Sam naziv Tjentište potječe od naziva za šator (tendu) pod kojima se prenoćivalo na putovanju. Tu poveznicu navodi i Jireček ("von tenta - tentorium"). C. JiREČEK, Die Handelsstrassen und Bergwerke, str. 76. Postoji i drugačije tumačenje kod D. Vujičića prema kojemu je korijen riječi tentus, u značenju stanice, što je Tjentište i bilo. Navedeno prema: S. IsAKović, "Tjentište u srednjem vijeku", str. 352.

48 D. Kovačević-KoJIĆ, Gradski život u Srbiji i Bosni (XIV-XV vijek), str. 148. 
Očito je ovaj lokalitet pokazao potencijal samo u vrijeme kasnoga srednjeg vijeka, dok je bio nezaobilazna točka i mjesto carinjenja na putu Via Drine, ali čak ni tada nije imao istinsku priliku da preraste u pravo naselje. Razlog tomu je svakako geografske prirode, naime uski prolaz, nedovoljno prostora za rast i razvoj naselja, nedovoljno plodne zemlje itd., to su posve sigurni razlozi zbog čega u neposrednoj blizini ni dan danas nema formiranoga naselja. Do ostataka grada danas ne vodi nikakva staza. Uza sam lokalitet vide se tragovi velikoga klizišta i obrušavanja kamenja. Mi smo lokalitetu pokušali i uspjeli pristupiti iz određene kosine, nešto niže od lokaliteta, gdje smo ušli u gustu i nepreglednu šumu i nakon mukotrpnoga uspinjanja, uspjeli smo izaći na jedan mali dio očito originalnoga puta pred sam izlazak na grad. ${ }^{49}$ Šma nadomak jedne od posljednjih pravih europskih prašuma - Perućice, je toliko gusta, da se nalazeći doslovce iznad ceste, nemoguće orijentirati sve do izlaska na sam vrh, jer se apsolutno ništa ne vidi od drveća. Sam izlazak na lokalitet je vrlo oštar. Uz njega se nalazi veliki odron kamenja koje klizi i iznimno je

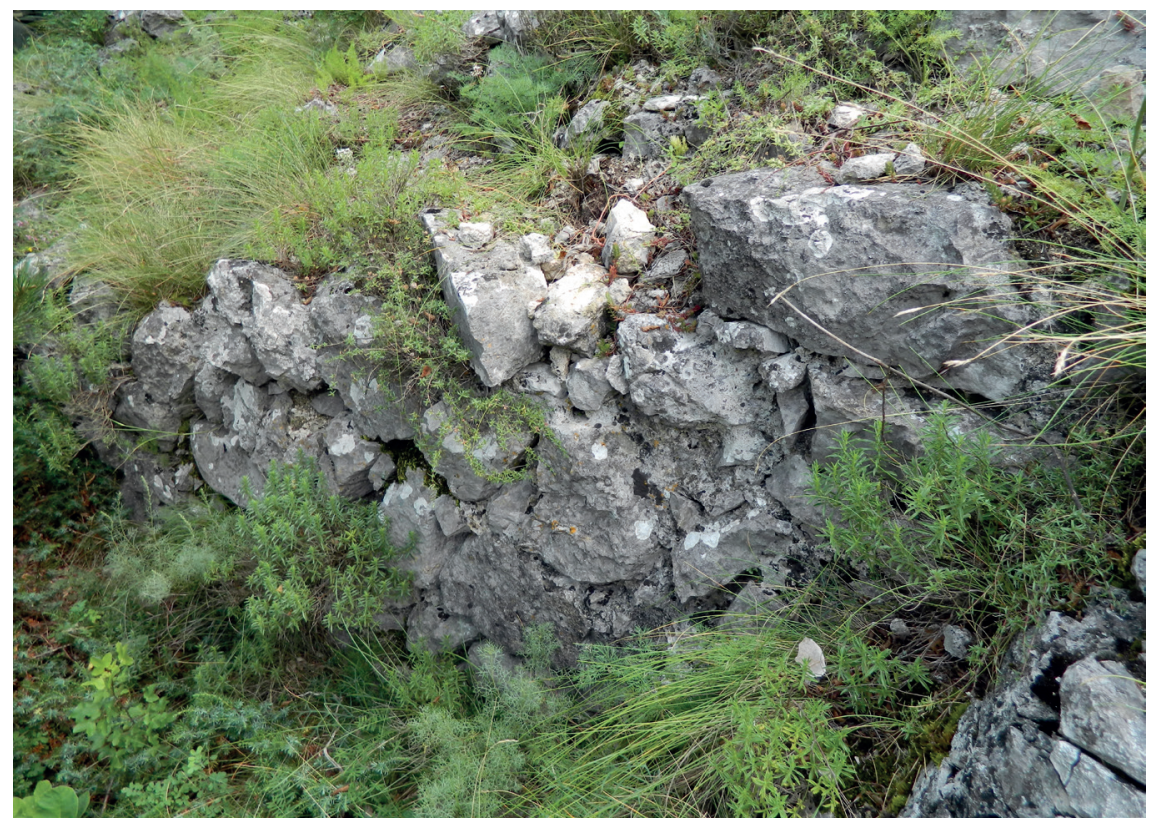

S1. 10. Dio vidljivih ruševina grada Vratara uza sam rub klisure (foto: Nina Čuljak)

49 Ovdje moram zahvaliti cijenjenoj doc. dr. sc. Dijani Pinjuh, sa Studija povijesti, koja je pristala uputiti se sa mnom na ovo doista opasno rekognosciranje. 
opasan. Odmah po izlasku na grad, dočekao nas je doista spektakularan pogled prema okolnim planinama, ali i dolini Sutjeske.

Od arhitekture, gore na samom rubu lokaliteta sačuvan je ostatak nekoga kružnog objekta upitne funkcije, budući da je riječ o suhozidu (tako da nije riječ o cisterni). Na rubu stijene očuvan je tek jedan jasno vidljiv dio srednjovjekovnoga zida. Orijentiran je sjeverozapad - jugoistok, sačuvan do visine od cca $70 \mathrm{~cm}$ i zidan u manje-više pravilnim redovima, uz nanose žbuke. Stratigrafska analiza (prema tzv. arheologiji arhitekture ${ }^{50}$ ) jedne ovakve utvrde (a naravno da bi joj trebala prethoditi arheološka istraživanja), mogla bi ponuditi pregršt informacija o arhitekturi i načinu zidanja. Te spoznaje mogle bi se dalje uspoređivati sa situacijom na drugim Hercegovim gradovima i utvrdama. Poznat je podatak da se za gradnju cisterni srednjovjekovnih gradova uglavnom dovodilo specijalizirane graditelje iz Dubrovnika (magistre a cisternis).$^{51}$ Primjerice, jedan od navoda poznatih iz objavljenih izvora jest onaj iz 1426. godine, ${ }^{52}$ u kojemu se spominje Radiša Bogetić, kamenar iz Dubrovnika, koji preuzima obvezu odlaska u "Sokol vojvode Sandalja" i koji će tamo izgraditi jednu cisternu "za koju će mu sav materijal dati Sandalj, hranu i piće i 8 groša dnevno". Ovo upućuje na zaključak da su cisterne radili strani (većinom dubrovački) graditelji, no može se pretpostaviti da su većinu ostalih gradnji ipak obavljali domaći graditelji i zidari. Karakteristike ovih gradnji mogu se samo jednim malim dijelom vidjeti na skromnim vidljivim ostatcima ove utvrde. Naša promišljanja idu u smjeru traženja određene "matrice", ili kvalitetnoga uzorka, za koji nije sporna

50 Nedestruktivne metode istraživanja povijesnih građevina u okvirima tzv. arheologije arhitekture (archeologia dell'architettura) relativno su nepoznate na našim prostorima. Međutim, mnoštvo je referentne literature na talijanskom i španjolskom jeziku. Riječ je o pokušaju primjene stratigrafske analize na vertikalnim strukturama zidova povijesnih građevina po principima ustaljenim u arheologiji (analiza stratigrafskih odnosa, faza gradnje, odnosno primjena Harrisove matrice). Pri tome se naravno uključuju i sve druge informacije do kojih se može doći, a koje u konačnici olakšavaju interpretaciju povijesne građevine. O arheologiji arhitekture više kod: Gian Pietro Brogiolo - Aurora Cagnana, Archeologia dell'architettura - metodi e interpretazioni, Firenze, 2012.; Roberto PArenti, "Arheologija arhitekture", u: Arheološki rječnik, 4452, Zagreb, 2014.

51 Aleksandar Ratković, Srednjovjekovni gradovi u Bosni i Hercegovini, Srpsko prosvjetno i kulturno društvo Prosvjeta, Mostar, 2005., str. 25.

52 D. Kovačević Kojić - V. Palavestra - Z. Kajmaković, "Drina u doba Kosača", str. 116. 
njegova vremenska pripadnost, te za koji ne postoji velika mogućnost kasnijega nadograđivanja. Cilj toga je usporedba s drugim lokalitetima iz istoga vremena. Išli smo tragom ubiciranja gradova za koje iz poznatih, prethodno spomenutih povelja Fridriha III. i Alfonsa V., znamo da su pripadali hercegu Stjepanu Vukčiću Kosači, ili pak nekih lokaliteta za koje postoji živa narodna tradicija da su pripadali hercegu Stjepanu, a za koje također postoji mala vjerojatnost nadograđivanja u turskom razdoblju. U tom smislu pokušali smo izdvojiti nekoliko lokaliteta, koji bi mogli ući u obzir. Jedan od njih je svakako Vratar u župi Sutiska, drugi je Hercegov grad u Zovom Dolu, a treći grad Mičevac kod Trebinja. Usporedbom načina gradnje može se zaključiti da su sva tri lokaliteta rađena u sličnom opusu. Manje-više nepravilno priklesano kamenje, vezano uz dostatne količine žbuke, na karakterističan način u sva tri slučaja. Jedino se zidovi najbolje očuvanoga Mičevca izdvajaju nešto većim stupnjem preciznosti prilikom klesanja kamenja i podizanja zidova, što i ne čudi, s obzirom na položaj Mičevca i njegovu svrhu, kao i mnogo veću povezanost s drugim zapadnim centrima (za razliku od ova dva visinska lokaliteta, koja su prije svega imale bitnu stratešku važnost). Pri tome treba imati na umu da je Mičevac doista i arheološki istraživan, te da je njegov istraživač Đ. Odavić, u više navrata konstatirao kako prema arheološkoj građi s provedenih sustavnih istraživanja nema naznake da grad nastavlja živjeti u tursko vrijeme, što znači da, ako je u nekom smislu kasnije i korišten, to nije sigurno podrazumijevalo veće graditeljske zahvate. Za lokalitet u Zovom Dolu, za koji smo od mještana doznali da se i dalje pamti kao "grad hercega Stjepana", došli smo također do zaključka da, iako se nalazi na putu koji se i dalje koristio u tursko vrijeme, njegova važnost opada s krajem srednjega vijeka (a samim time i potreba nekih većih gradnji i dogradnji). Ovo smo zaključili čitajući Putopis znamenitoga turskog putopisca Evlije Čelebija iz XVII. st., koji je, prolazeći kroza Zovi Do, konstatirao da je to bilo "ranije napredno naselje", što ukazuje na činjenicu da je njegova važnost već u XVII. st. potpuno izgubljena. ${ }^{53}$

53 Ovdje želimo kazati da smo na terenu naišli na najnovije devastacije (doduše nehotične, iz neznanja, neinformiranosti i neoznačenosti lokaliteta) u širem gradskom podgrađu, na položaju Banj-do, Stolovi, gdje je jedna od tri srednjovjekovne kamene stolice u potpunosti uništena prilikom novijih građevinskih radova u neposrednoj blizini. 
Hercegovina - 4 - 2018., str. 173-199

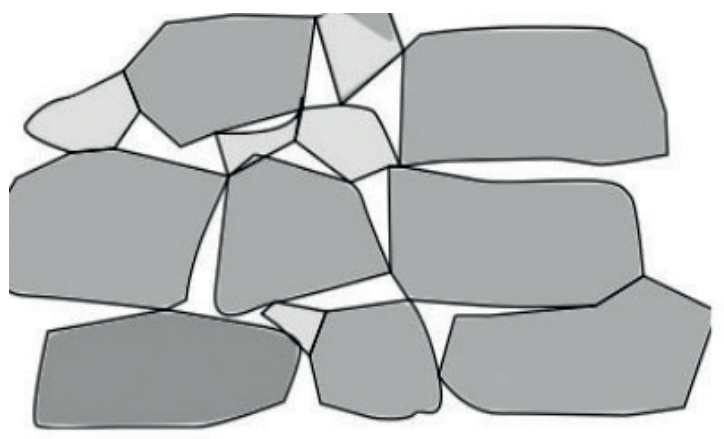

VRATAR

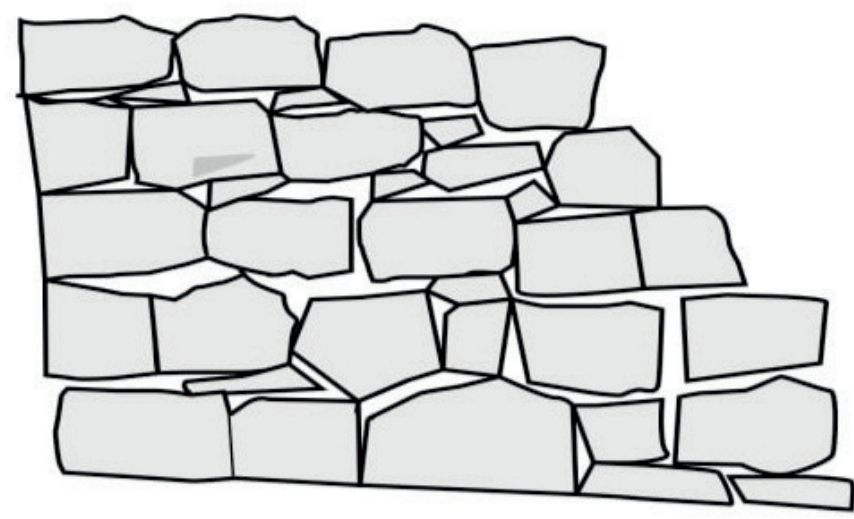

MIČEVAC

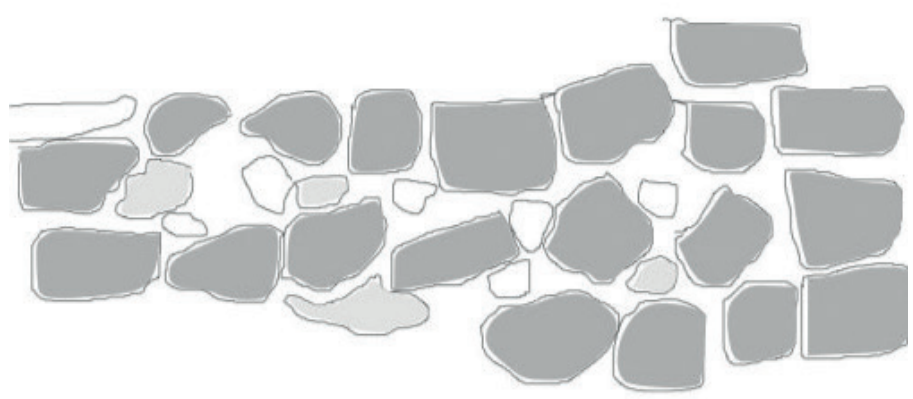

ZOVI DO

Sl. 11. Skica opusa gradnje s tri Hercegova grada (crtež: Nina Čuljak) 
U svakom slučaju, ovo su tek naznake promišljanja o ovim lokalitetima, koje u pravom smislu mogu biti nadopunjene isključivo novim arheološkim istraživanjima, a svakako i nekim novim, ili zanemarenim podatcima iz povijesnih izvora. Ovo bi svakako bila jedna tema sama za sebe, koja bi zahtijevala dugo i sustavno istraživanje. U ovom smislu može se reći da postoje i drugi lokaliteti koji bi došli u obzir za usporedbu. Tu je primjerice grad Ključ kod Gacka, koji je čak pozicioniran tako da gravitira putu Via Drine, a njegova je arhitektura čak dobro sačuvana, ali je lokalitet apsolutno zanemaren, u svakom mogućem smislu. U trenutku našega obilaska, od nepreglednoga raslinja tek se u ograničenom smislu moglo pristupiti lokalitetu.

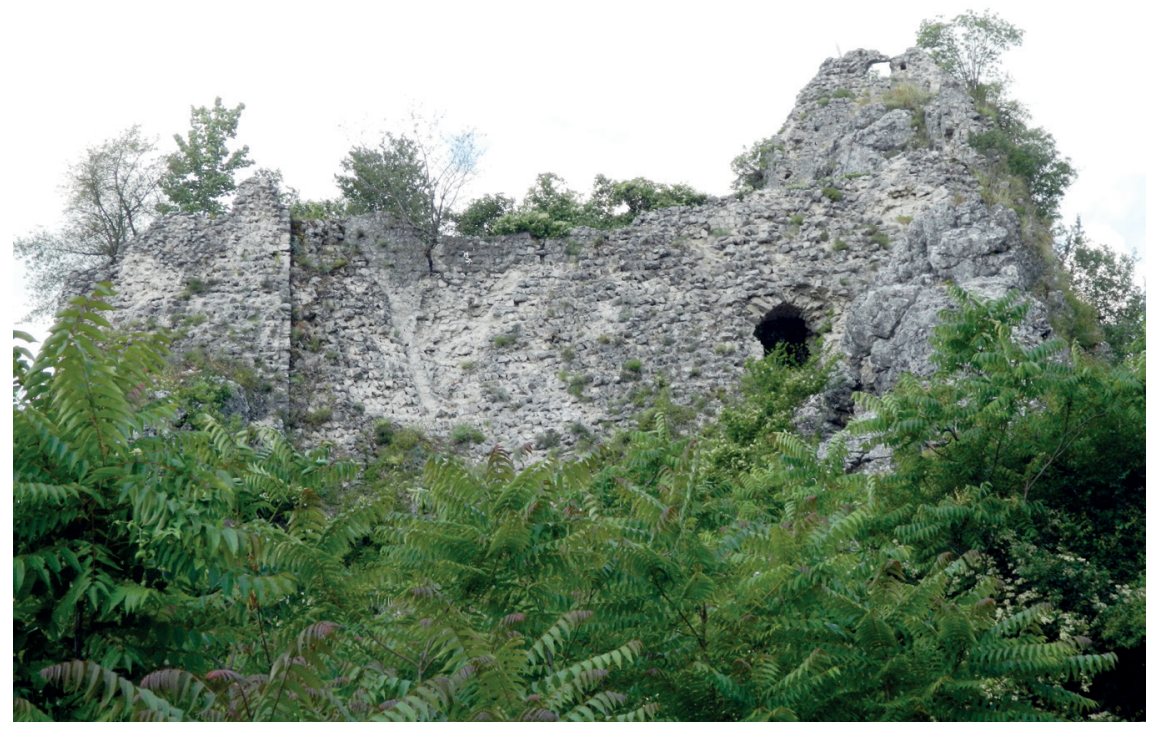

Sl. 12. Pogled na srednjovjekovni grad Ključ kod Gacka (foto: Nina Čuljak)

Važno je istaknuti da bi bilo najbolje provesti arheološko istraživanje jednoga ovako značajnoga srednjovjekovnog grada, jer je pristup njemu (ukoliko se naprave pripremni radovi) veoma lagan, a ostatci su doista impozantni, i to je lokalitet koji bi se mogao veoma lijepo uklopiti u turističku ponudu, i oživjeti taj gotovo napušteni kraj. Rezultati sustavnih istraživanja bili bi od velike važnosti za znanost. Ono što je doista tužno i poražavajuće jest činjenica da smo diljem Hercegovine nailazili na kasnosrednjovjekovne spomenike posve 
zanemarene, zapuštene, često neoznačene, dodatno uništene itd., pa se nadamo da će ovaj rad na neki način pomoći da se ovi lokaliteti otrgnu od zaborava.

\section{Zaključak}

Cilj ovoga rada nije samo skretanje pažnje na uništene, zapostavljene, neoznačene i nezaštićene lokalitete (a grad Vratar je eklatantan primjer toga) nego, eo ipso, i poticanje na promišljanja o onome što bi nam arheološka istraživanja ovoga i sličnih gradova/utvrda mogla ponuditi. Naime, riječ je o svojevrsnim orijentirima i oglednim primjercima gradnje svoga vremena i prostora, koji nam mogu dati odgovore na pitanje izgradnje i funkcioniranja jednoga srednjovjekovnog grada - utvrde. Ovdje, naime, govorimo o sretnim okolnostima gubljenja važnosti visinske pozicije utvrde, koja vjerojatno $\mathrm{u}$ rano tursko doba postaje suvišna, prvenstveno zbog promjene $\mathrm{u}$ načinu ratovanja i općenito drugačije vojne i carinske organizacije u turskom razdoblju, odnosno kontrole iste. Činjenica je da je ovaj prolaz ipak ostao i dalje opasan za promet i tijekom XVI. st. ${ }^{54}$ no to su drugačije okolnosti kako posjedovanja, tako i osiguravanja važnih punktova. O ovome bi svakako povjesničari koji istražuju tu problematiku mogli mnogo više reći. No, činjenica je da je utvrda Vratar sustavno propadala od kasnoga srednjeg vijeka i njezino arheološko

54 Podatak o upućivanju pisma Porti u kojem se upozorava na opasnost klanca pod nazivom Sutiska (Sutjeska), za koji se kaže da bi se trebao čuvati, tj. imati stražu (podatak se odnosi na 1560. god.) vidjeti u: Muhimme Defteri, knj. 1, sv. 1, Sarajevo, 1985., str. 61. Već ovaj podatak u kojemu nema spomena utvrdi Vratar govori o prestanku korištenja, i činjenici da se "obrana" spušta u uvjetno rečeno - podgrađe. Slična je situacija i u Blagaju, koji je za razliku od Vratara ipak koliko-toliko održavao kontinuitet korištenja same utvrde - tj. grada i stoljećima kasnije, a ipak, u XVII. st. E. Čelebi zatiče prazan grad, dok se život koncentrirao i organizirao u gradskom podgrađu. EvLIJA ČELEBI, Putopis, Svjetlost, Sarajevo, 1967., str. 453. U slučaju Blagaja tu je naravno važno i postupno jačanje Mostara, koji mu preuzima ulogu koju je stoljećima imao. Glede podatka o Vrataru svakako treba imati na umu da je tu vjerojatno riječ o čuvanju straže jednoga, ili više mještana, koji su to često činili na način da su motrili prolaz i udarcima u neki vid bubnja upozoravali na neku opasnost na putu. Ovo znamo iz putopisa iz XVI. st., iz kojih se vidi da su mještani zaduženi za čuvanje straže bili zauzvrat oslobođeni od harača. O tomu vidjeti: SRĐAN Rudić, "Pljevaljski kraj u putopisima XVI veka", u: Glasnik Zavičajnog muzeja, knj. 2, Pljevlja, 2001., str. 128-136. Ovo nam zapravo daje sliku na koji način je dalje funkcionirala "straža" i na ovom lokalitetu. Dakle, to je jedno posve novo vrijeme i drugačije okolnosti. Nekadašnji značaj utvrde je izgubljen. 
istraživanje moglo bi ponuditi posve nove rezultate, a samim time pokrenuti i nova promišljanja o problematici kasnosrednjovjekovnoga fortifikacijskog graditeljstva, ali i načina ratovanja. Kada se danas promatra lokalitet Vratar, u svom prostornom okruženju, ne možemo se oteti dojmu o svojevrsnoj protočnosti i poveznici prošlosti i sadašnjosti. Naime, današnja državna magistrala se dijelom poklapa sa starim makadamskim putom, kojim su stoljećima prolazile trgovačke karavane, i čija je važnost bila golema za tadašnju privredu. Potom, današnje odmorište u Tjentištu je i u srednjem vijeku imalo funkciju odmorišta. Promatrajući povoljan smještaj hotela Mladost, nismo mogli ne zapitati se kako i gdje je točno na tom pogodnom proširenju bio smješten znani Kosačin domus, a gdje carina, šatori, kako je sve to funkcioniralo tada... Jedino je utvrda, koja i sada sa svoje dominantne kote "motri" na Sutjesku, na put i veličanstvene planinske vijence okoliša, izgubila svoju nekadašnju funkciju, ali sudbinski je ipak ostala zabilježena u nazivu tunela koji je smješten u njezinu podnožju. Život se i ovdje ipak nastavlja, iako na nešto drugačiji način. Ovaj lokalitet bi bilo potrebno arheološki istražiti i zaštititi od konačnoga raspadanja, ili ga barem adekvatno obilježiti i na taj način sačuvati od potpunoga zaborava. 


\section{The Town of Vratar (Sutiska) on the Via Drina Road}

\section{Summary}

The paper presents the results of research on the late medieval town of Vratar (Sutiska), based on published historical records and personal archaeological-topographic studies of the fort and its wider area. Apart from turning attention to the town itself or its modest architectural remains, which we personally reviewed and photographed, we also focus on its location on the medieval road known as the Via Drina. Our archaeological-topographical research on this and wider area has shown that all important medieval cities were positioned near several basic medieval roads, which in fact were the reason for their existence. The research found that the preserved architecture of the town of Vratar, due to its limited duration at the end of the late Middle Ages, was an exemplary of the building opus that was applied in the fortification architectural era. In that sense, comparisons were made with other cities that we know were in the possession of the Herzog Stjepan Vukcic Kosaca and lost their importance after the Ottoman conquest. This was, for example, the situation with Micevac, and, possibly, Zovi Dol. The aim of the paper is to emphasize the importance of these localities, but also to warn that they are both archaeologically unexplored and totally neglected by the public.

Keywords: Herzegovina; medieval towns; Via Drina; the towns of Herzog Stjepan Kosaca; the Fort Vratar (Sutjeska/Sutiska). 